\title{
CORRIGENDUM TO “REVIEW OF PRODUCT INTEGRATION BY JOHN D. DOLLARD AND CHARLES N. FRIEDMAN"
}

\author{
BY MICHAEL A. FREEDMAN
}

In my review of Product integration by J. D. Dollard and C. N. Friedman, which appeared in the March 1982 issue of this Bulletin (Bull. Amer. Math. Soc. (N.S.) 6 (1982), 230-233), it was erroneously stated that equation 3.6 on page 135 of their book was incorrect. I regret my error in this matter.

Department of Mathematics, Vanderbilt University, Nashville, TenNESSEe 37235 